\title{
Fifty years! The New Zealand Journal of Education Studies (NZJES) Te Hautaki Mātai Mātauranga o Aotearoa 1966-2015
}

\author{
Roseanna Bourke ${ }^{1} \cdot$ Judith Loveridge $^{1}$
}

Published online: 25 August 2015

(C) New Zealand Association for Research in Education 2015

Fifty years ago in May 1966 the first volume of the New Zealand Journal of Education Studies (NZJES) was launched by the founding Editor Professor P. J. Lawrence (University of Canterbury). At a cost of 30 shillings a year for two issues, the first issue contained six articles and five book reviews, thus starting fifty years of exploring educational policy, practice and philosophical issues relevant for our times. At first glance, it could be argued that little has changed. The articles include a mix of qualitative and quantitative research on issues such as indigenous education, the teaching of literacy, understanding learning, historical events of note, and the impact of policy. The New Zealand Official Year-Book, 1966 identified the 'trends and problems' in education as:

the dramatic increase in the school population during the post-war years. At a time when smaller classes were being planned for, the intake of pupils became greater than ever before and this slowed up the move to reduce the size of classes. Such reduction, however, is still regarded as a major educational objective. The problem has been complicated by a general shortage of adolescent labour and there has been difficulty in training sufficient teachers to staff the schools.

The Official Yearbook (1966) also identified "individual differences among children; study of subject-matter that has real meaning for children; free secondary education for all; and developments in the field of advanced technical education to meet needs arising from the expansion and diversification of industry". These trends

Roseanna Bourke

roseanna.bourke@vuw.ac.nz

1 Wellington, New Zealand 
and issues reflect the interests of educational researchers then, and continue to do so 50 years later.

However, the way the issues are framed, and the language used, provides a clue that we are looking back over the 50 years. In 1966 it was notable that although there was concern around the "continued under-representation of the Maori people in the sixth forms, at the universities, and in skilled and professional occupations" (Barrington, 1966, p. 1), engagement with the issue was from a dominant paradigm of privilege. For example, it was observed that "In recent years, considerable emphasis has been placed upon the education of New Zealand Maori, and in particular, upon the racial disparities in educational achievement" (Lovegrove 1966, p. 15). Researchers felt they were 'doing good' but through an approach we might now question. McCreary (1966) investigated reading with Māori children having "in 1958 subjected the children of the local Maori school to a battery of educational tests" (p. 40). McCreary reported that the results of the tests left "little doubt as to their Maoriness" (p. 4) but made clear there was not "any single cause of Maori educational retardation" (p. 40). Within this first issue there is evidence that although the educational research agenda may be comparable to that of today, there has been a fundamental shift in the way that both Māori and Pākehā engage as researchers. Specifically, today there is a strong desire to explore the contextual, political, cultural and organisational structures that impact on learner progress and to untangle, debate and challenge the status quo if we are to ensure equity for all learners.

In 1986 the NZJES journal editors, Professors David McKenzie and Ted Glynn, invited those with strong connections to the journal to offer their reflections on future direction, as they celebrated twenty years of the journal. For Prof Philip Lawrence, one of his 'unrealised hopes' was that NZJES had not broadened its range of contributors, but rather had become "a house journal for the publications of university lecturers in education" (Lawrence 1986, p. 88), and suggested that this may relate to the need for promotions (in 2015 for promotion we could read Performance Based Research Fund). Prof Snook on the other hand, was optimistic that "there are signs that some educationalists are now ready to collaborate with colleagues to address issues of policy and practice" (p. 93). For Snook, a concern at the time was that "specialists saw themselves as working in branches of the parent disciplines and were happiest when fraternising with their academic dads and mums" (Snook 1986, p. 93). What Snook really wished for was to see academics from a range of discipline backgrounds working together to inform policy and practice, to benefit policy makers and teachers alike.

To celebrate the first 50 years of publication of the New Zealand Journal of Educational Studies (NZJES), we invited researchers who have had a long involvement with New Zealand educational research to submit articles that look back at and forward from the issues that have been examined in the journal over time. In this issue we look back. The next issue 50(2) will move our gaze forward to the issues that may preoccupy today's researchers into the future. Liz Gordon's retrospective contribution is published in this issue. As a previous Editor of NZJES, an independent educational researcher and a past President of New Zealand Association of Educational Research, Gordon characterises the 50 years during 
which NZJES has been published as bifurcated by a policy shift in the 1980s; a shift from a social democratic discourse of equality for all to a neoliberal discourse of market choice for the privileged. She argues that "the kaupapa that binds our research community" across the period as a whole is research that aims to realise a heritage which stresses "the right, as citizens, to a good education in a society that provided opportunity for all". Gordon exemplifies this kaupapa as she examines how the school system has changed as a result of Tomorrow's Schools by revisiting the empirical effects of school choice and social inequality. Gordon first examined this issue in 1994. That study then led her to question whether choice could be seen as desirable if it results in unequal access to educational opportunities. Her analysis of changes over the period of 1996-2014 shows that "rich" schools have got larger and "poor" schools have got smaller. While more Māori and Pacific Island students do now attend decile ten schools, lower decile schools have predominantly Māori and Pacific Island student populations. Twenty years on Gordon argues that despite national and international failure of choice policies they have not been abandoned but, rather, intensified.

The other articles that appear in this issue continue the research community kaupapa that Gordon identified as today's researchers investigate diverse questions across all sectors of education, employing a range of methodologies, in an effort to produce research that will make a difference and lead to a good education. Kimai Tocker documents the history of beginning of the Kura Kaupapa Māori movement at a time when the shift in discourse from equality for all to market choice was occurring. She explores political strategies that were used in the long and arduous battle to ensure legislation that would include Kura Kaupapa Māori as a distinct legal category within the Education Act rather than as one of the minority groups able to exist through an 'opt out' clause within the emerging discursive context of market choice and charter schools.

Hana Turner, Christine Rubie-Davies and Melinda Webber examine the relationship between secondary school teachers' expectations, and student ethnicity and achievement in mathematics. Teachers' perceptions of the factors contributing to the achievement gap between Asian, Māori, Pacific Island and Pākehā are also investigated. Alex Hotere-Barnes' article addresses ways that Pākehā researchers can contribute to the educational well-being of Māori. He critically examines forms of Pākehā paralysis in regard to addressing diverse Māori educational aspirations. Reflecting on his own research experiences he explores possible roles for Pākehā in Māori educational research and proposes non-stupid optimism, as an opportunity to "revitalise the zones of imagination between Māori and Pākehā educational researchers".

Anne Smith draws attention to an area urgently needing research. Home-based early childhood education (HBECE) services are the fastest growing in the early childhood education sector but, as Smith reveals, very little research has been conducted nationally or internationally on HBECE. She reviews the extant studies that are relevant to determining critical components of quality in HBECE. She argues that the "extreme paucity of research" in New Zealand is a limitation on any initiatives to improve quality of HBECE.

John Hattie, Gavin Brown and Earl Irving report findings from two studies that focussed on School Entry Assessment (SEA) kit. SEA is administered in the first 
6-8 weeks of students attending school to identify students' strengths and gaps in reading and number, and to inform teaching and learning strategies. The first study examines the item and structural characteristics of the instruments and the second study examines the predictive value of the SEA by examining the relationship between performance on the SEA with performance on other routinely administered assessments at age 6 and in year 5. Recommendations are made for revising the SEA and its administration, and critically examining the use that is made of the information from such assessments for confirming or disconfirming practices so as to make a difference for all students.

Leon Benade critically analyses the model of practitioner inquiry and research "Teaching as Inquiry" (TAI) and discusses research findings from a study of primary and secondary teachers about their understanding of reflective practice. He argues for a model of collaborative, critical teacher reflective practice that might more accurately reflect the focus on teachers as inquirers. Averil Coxhead, Paul Nation and Dalice Sim investigate the factors influencing the vocabulary size of young people in secondary schools for whom English is their first language. Terry Locke examines writing practices in an intensive professional development workshop that impact on teacher self-efficacy with regard to writing and teaching writing. The practices that appear to impact positively on student motivation and writing are also examined. Suzanne Manning reports on a small project conducted in a polytechnic to examine the perceived effectiveness of partnerships between academic advisors and subject tutors in supporting students in the literatures of their specific disciplines.

The first issue of NZJES reflects the language of its time. It serves a timely reminder that how we present our research in part reflects what we value, and in part what we believe. Values and beliefs shape how we report and interpret research findings. It would be rare to see the language of 50 years ago used in the journal now. References to 'Maori educational retardation' (McCreary 1966) or 'intellectually deficient children' and 'mentally retarded children' (Nuthall 1966) would not be acceptable today. Indeed, substantial changes of value and belief over time in terms of how we position learning and learners, even among the same researchers are evident, for example in the language of Nuthall's later work in classrooms (Nuthall 2007). At the heart of the kaupapa remains a common thread of researchers setting out to support improvements in learning by understanding the barriers to and enablers of learning. In turn, the way our current discourse and educational research practice is viewed in 50 years time may appear crude and unsophisticated as collective knowledge and understanding of educational practice grows.

As the current editors of NZJES, our hope is that educational researchers in Aotearoa New Zealand cherish the kaupapa that commenced 50 years ago, and that through their own research lens (indigenous, philosophical, educational psychology, sociology, historical, cultural studies or policy scholarship) they contribute to an evolving understanding of how education works for the benefit of all. Researchers investigate, report and disseminate what matters most to them, in order to make sense of the educational and social challenges of today. Dissemination of this research through NZJES helps to create a dialogical community of local researchers, 
practitioners and policy makers. As we look to the next 50 years, we welcome your contributions to keep these research disturbances alive.

\section{References}

Barrington, J. M. (1966). A historical review of policies and provisions. New Zealand Journal of Educational Studies, 1(1), 1-14.

Lawrence, P. (1986). Twenty years on. New Zealand Journal of Educational Studies, 21(2), 86-89.

Lovegrove, M. N. (1966). The scholastic achievement of European and Maori children. New Zealand Journal of Educational Studies, 1(1), 15-39.

McCreary, J. R. (1966). Reading tests with Maori children. New Zealand Journal of Educational Studies, 1(1), 40-50.

Nuthall, G. A. (1966). Research and theory on the cognitive development of the intellectually deficient child. New Zealand Journal of Educational Studies, 1(2), 113-125.

Nuthall, G. (2007). The hidden lives of learners. Wellington: NZCER Press.

Snook, I. (1986). Twenty years on. New Zealand Journal of Educational Studies, 21(2), 92-93.

Statistics New Zealand (1966). The New Zealand Official Year-Book, 1966. Retrieved from http://www3. stats.govt.nz/New_Zealand_Official_Yearbooks/1966/NZOYB_1966.html\#idchapter_1_62391 